\title{
Risankizumab (Skyrizi)
}

\author{
MUDr. Jiří Horažd'ovský, Ph.D. \\ Dermatovenerologické oddělení Nemocnice České Budějovice, a. s.
}

Znalost imunopatogenetických mechanismů psoriázy rozšiřuje možnosti ovlivnění tohoto onemocnění o další cílenou terapii. V celé kaskádě imunitní reakce se jako klíčový ukazuje interleukin 23 (IL-23). Risankizumab je další biologikum s cílenou inhibicí IL-23. Článek shrnuje léčebné možnosti tohoto léčiva a vlastní první klinické zkušenosti.

Klíčová slova: psoriáza, interleukin 23, biologická léčba, risankizumab.

\section{Risankizumab (Skyrizi)}

Imunopatogenetic mechanisms of psoriasis extend our possibilities for new targeting therapy. The crucial importance of interleukin 23 (IL-23) was recognized. Risankizumab is the next biologic drug with target inhibition of IL-23. Article summarizes the therapeuric potential of this drug and gives the first clinical experiences by myself.

Key words: psoriasis, interleukin 23, biologic therapy, risankizumab.

\section{Úvod}

Psoriáza je definována jako chronické, systémové, autoinflamatorní onemocnění, které postihuje celosvětově přibližně 100 milionů lidí (1). Pro tuto svou vysokou prevalenci predstavuje závažný globální problém, řešený i na úrovni Světové zdravotnické organizace (WHO) (2).

Pacienti s psoriázou vykazují zvýšené riziko rozvoje nejrůznějších komorbidit, včetně kardiovaskulárních onemocnění, depresí, metabolického syndromu, kloubního postižení, střevních zánětlivých onemocnění, která komplexně znamenají výrazné zhoršení kvality života a statisticky též zkrácení délky života $(3,4)$

Etiologie psoriázy je multifaktoriální, onemocnění vzniká u geneticky predisponovaných jedinců pưsobením environmentálních vlivư (např. životní styl, infekce apod.). V patogenezi psoriázy se uplatňuji především dendritické buňky a regulační a pomocné (Th1 a Th17) lymfocyty, jejichž aktivita je spojena s vysokou expresí prozánětlivých cytokinů, jako TNF-a, IFN-ү, IL-12, IL-17 nebo IL-23 (5).

Perspektivy pacientů s psoriázou se výrazně zlepšily v souvislosti se zavedením cílené biologic- ké terapie. Biologická terapie byla v České republice poprvé použita v roce 2002 (psoriatická artritida), resp. 2004 (psoriáza), spektrum biologických léků se stále rozšiřuje právě v souladu s rostoucími poznatky o imunopatogenetických mechanismech u psoriázy (6).

Hlavní regulační cytokin, IL-23, hraje zásadní roli v diferenciaci, aktivaci a přeživání T helper 17 (Th-17) buněk. U psoriázy je aktivována osa IL-23/ Th-17, která způsobuje chronický zánět a tvorbu psoriatických ložisek $(7,8)$.

Klinické studie prokázaly, že selektivní inhibice IL-23 pomocí protilátek proti podjednotce p19 IL-23, má vysoký a dlouhodobý efekt ve spojení s redukcí exprese prozánětlivých cytokinů v kůži. Navíc selektivní inhibice IL-23 nabízí následně lepší bezpečnostní profil než ta biologika, která cíleně blokují interleukin IL-17 (9). Dochází k selektivní blokádě diferenciace pouze patogenních Th17 lymfocytů, nepatogenní Th17 lymfocyty se nadále diferencují a produkují fyziologické hladiny IL-10 a IL-17, fyziologická hladina IL-17 je nutná k udržení ochrany bariérové funkce kůže sliznic před specifickými patogeny (včetně kandidových) (obr. 1).
Jedním z nejnovějších poznatků je zjištění, že selektivní inhibice IL-23 pravděpodobně aktivuje protizánětlivou pamět tlumením TRM (Tissue Resident Memory) lymfocytů, které jsou odpovědné za opětovné zánětlivé vzplanutí již zhojených ložisek. Tímto se prodlužuje léčebná odpověd' (10)

\section{Charakteristika přípravku}

Risankizumab je humanizovaná monoklonální protilátka lgG1, která se selektivně a s vysokou afinitou váže na unikátní podjednotku (p19) interleukinu-23 (IL-23), čímž inhibuje interakci IL-23 s receptorovým komplexem IL-23 a dostředivou buněčnou signalizaci závislou na IL-23. IL-23 je významným regulátorem diferenciace, přeživání a aktivity různých imunitních buněk, zejména Th17-lymfocytů, Th22-lymfocytů či prirozených lymfoidních buněk (ILC), které produkují prozánětlivé cytokiny (např. IL-17, IL-22 či TNF-a).

Jedná se pouze o selektivní blokádu IL-23, která neovlivňuje diferenciaci nepatogenních Th-17 lymfocytů. Tímto zůstává zachována fyzio-

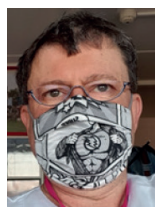

Cit. zkr: Dermatol. praxi 2020; 14(2): 91-95

Článek prijiat redakcí: 23. 4. 2020

Článek príijat k publikaci: 24. 5. 2020 


\section{FARMAKOLOGICKÝ PROFIL}

\section{RISANKIZUMAB (SKYRIZI)}

Obr. 1. Mechanismus účinku risankizumabu

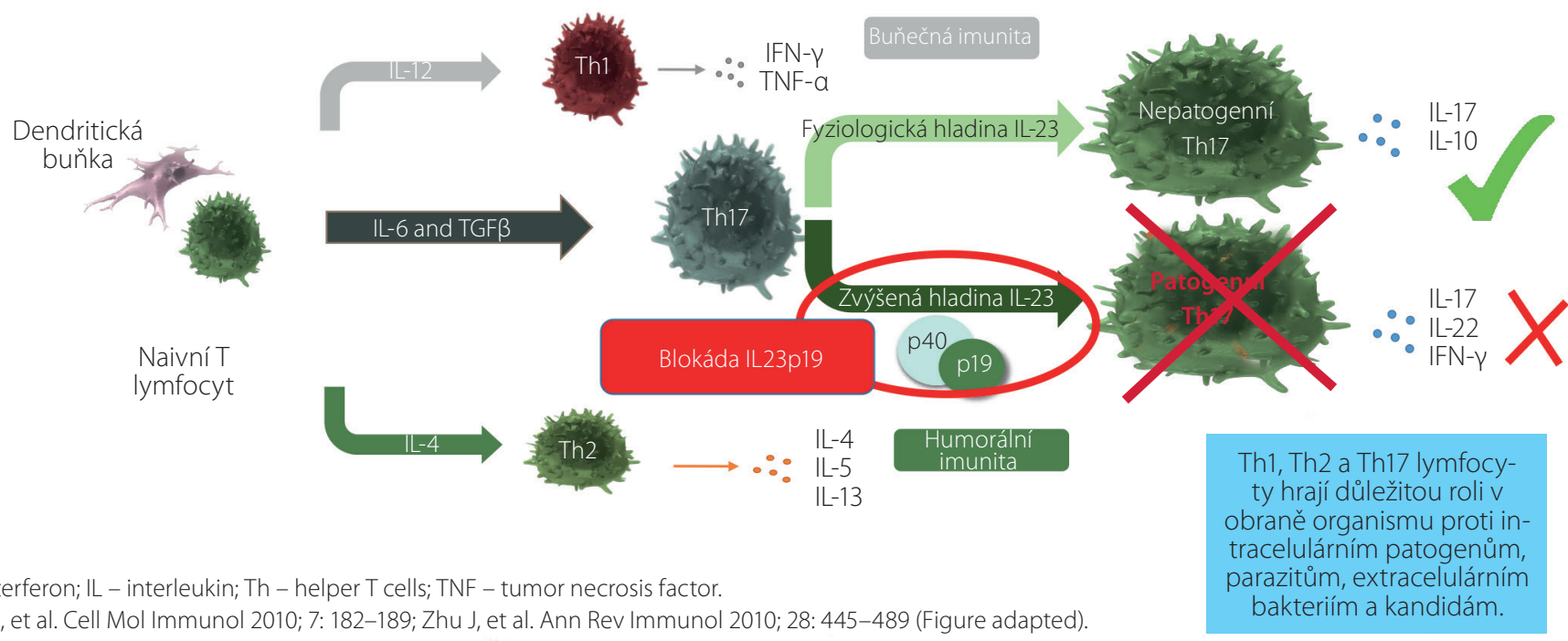

Leung S, et al. Cell Mol Immunol 2010; 7: 182-189; Zhu J, et al. Ann Rev Immunol 2010; 28: 445-489 (Figure adapted).

logická homeostáza na sliznicích. Risankizumab byl registrován v březnu 2019 v Japonsku pro terapii psoriázy (včetně erythrodermické a generalizované pustulózní) a psoriatické artritidy, v dubnu 2019 pak byl registrován FDA (Food and Drug Association) a EMA (European Medicines Agency). Je indikován k léčbě středně těžké až těžké ložiskové psoriázy u dospělých pacientů, kteří jsou kandidáty na systémovou terapii. Doporučená dávka je 150 mg (dvě 75 mg injekce = 1 balení) podaná subkutánně v týdnu 0 , týdnu 4 a následně každých 12 týdnů $(11,12,13)$.

\section{Účinnost v klinických studiích}

Účinnost risankizumabu u dospělých pacientů se středně těžkou až těžkou ložiskovou psoriázou byla hodnocena v klinické studii II. fáze (14) a ve čtyřech klinických studiích III. fáze (UltiMMa-1, UltiMMA-2, IMMhance a IMMvent) (15, 17-19).

Studie II. fáze byla 48týdenní multicentrická randomizovaná studie, do které bylo zařazeno 166 nemocných s chronickou ložiskovou psoriázou s hodnotami BSA (Body Surface Area) $\geq 10$, PASI (Psoriasis Area Severity Index) $\geq 12$ a sPGA (static Physician's Global Assessment) $\geq 3$. Pacienti byli náhodně prriřazeni k terapii risankizumabem v týdnech 0, 4 a 16 s. c. nebo k léčbě ustekinumabem $v$ týdnech 0, 4 a 16 s.c. Primárním sledovaným ukazatelem byl podíl nemocných s odpovědí PASI 90 ve 12. týdnu, k sekundárním sledovaným parametrům patrily podíly pacientů s odpověd'mi PASI 50, PASI 75, PASI 90, PASI 100 či sPGA 0/1 $\checkmark$ různých časových bodech. Vyhodnocován byl rovněž vliv léčby na psoriatické postižení kštice (skóre PSSI - Psoriasis Scalp Severity Index), dlaní a plosek (skóre PPASI - Palmoplantar PASI) či nehtů (skóre NAPSI - Nail Psoriasis Severity Index) a na kvalitu života pacientů (skóre DLQI - Dermatology Life Quality Index) (14).

Ve studii byla prokázána výrazně vyšší účinnost risankizumabu oproti ustekinumabu - odpověd'PASI 90 byla ve 12. týdnu dokumentována u 73 \% (dávka 90 mg), resp. 81 \% (dávka 180 mg) pacientů, vs. $40 \%$ pacientů $(p<0,001)$, odpověd' PASI 100 u $41 \%$, resp. $48 \%$, vs. $18 \%$, a odpověd' sPGA 0/1 u $90 \%$, resp. $88 \%$, vs. $62 \%$ pacientů. Nástup účinku risankizumabu byl rychlejší a účinek této léčby byl trvalejší v porovnání s ustekinumabem. Skóre DLQI 0 či 1 bylo ve 12. týdnu zaznamenáno u 72 \% pacientů ze skupin risankizumabu vs. u 53 \% nemocných ze skupiny ustekinumabu. Léčba risankizumabem vedla rovněž k výraznějšímu a trvalejšímu poklesu skóre PSSI či NAPSI a k výraznějšímu poklesu skóre PPASI (14).

Studie UltiMMa-1 a UltiMMa-2 byly 52týdenní multicentrické, randomizované, dvojitě zaslepené studie III. fáze (s identickým designem), do kterých bylo zařazeno 506, resp. 491, pacientů s chronickou ložiskovou psoriázou s hodnotami BSA $\geq 10$, PASI $\geq 12$ a sPGA $\geq 3$. Nemocní byli $\checkmark$ poměru $3: 1: 1$ náhodně přiřazeni $k$ léčbě risankizumabem (150 mg s. c.), k terapii ustekinumabem (45 mg nebo 90 mg dle tělesné hmotnosti), nebo k podávání placeba v týdnech 0, 4, 16, 28 a 40. Koprimárním sledovaným ukazatelem bylo dosažení odpovědi PASI 90 a sPGA 0/1 v 16. týdnu, mezi sekundární sledované ukazatele patřily četnosti odpovědí sPGA 0, PASI 100, DLQI 0/1 či PSS (Psoriasis Symptom Scale 0) (15).
I v těchto studiích byla prokázána výrazně vyšší účinnost risankizumabu oproti ustekinumabu: odpověd’ PASI 90 byla v 16. týdnu prokázána u 75 \% pacientů (v obou studiích) ze skupiny risankizumabu vs. u 5 \% (studie UltiMMa-1), resp. 2 \% (studie UltiMMa-2) pacientů ze skupiny placeba vs. u $42 \%$, resp. $48 \%$ pacientů ze skupiny ustekinumabu. Odpověd' sPGA 0/1 byla v 16. týdnu zjištěna u $88 \%$, resp. $84 \%$ (risankizumab), vs. $8 \%$, resp. $5 \%$ (placebo), vs. $63 \%$, resp. $62 \%$ (ustekinumab). Úplného vymizení projevů psoriázy (sPGA 0/1, resp. PASI 100) dosáhlo v 16. týdnu ve studii UltiMMA-1 37\%, resp. $36 \%$ pacientů léčených risankizumabem, vs. $14 \%$, resp. $12 \%$ nemocných léčených ustekinumabem, vs. $2 \%$, resp. $0 \%$ pacientů z placebové skupiny; identické výsledky byly pozorovány i ve studii UltiMMa-2 (15).

Studie IMMhance byla multicentrická, randomizovaná, dvojitě zaslepená placebem kontrolovaná studie, do níž bylo zařazeno 507 pacientů s chronickou ložiskovou psoriázou s hodnotami $B S A \geq 10, P A S I \geq 12$ a sPGA $\geq 3$. Na začátku první části studie byli pacienti v poměru 4 : 1 randomizováni k terapii risankizumabem (150 mg s. c.) nebo k podávání placeba v týdnech 0 a 4 ( $v$ 16. týdnu byla všem nemocným podána dávka risankizumabu); koprimárním sledovaným parametrem v této části bylo dosažení PASI 90 a sPGA 0/1 v 16 týdnu. Ve druhé části studie (týden 28-104) byli pacienti původně léčení risankizumabem, kteři dosáhli odpovědi sPGA 0/1 ve 28. týdnu, v poměru $2: 1$ znovu randomizováni k terapii risankizumabem (udržovací léčba), nebo k uživání placeba (přerušení léčby), přičemž nemocným, u nichž došlo po 32. týdnu k relapsu (sPGA $\geq 3$ ), byl opět 


\section{INZERCE}




\section{FARMAKOLOGICKÝ PROFIL}

\section{RISANKIZUMAB (SKYRIZI)}

nasazen risankizumab. Primárním sledovaným parametrem ve druhé části studie bylo dosažení sPGA 0/1 v 52. týdnu (16, 17). Risankizumab potvrdil dlouhodobou účinnost: $61 \%$ pacientů si udrželo PASI 100 po dobu 2 let, 78 \% pacientů si udrželo PASI 90 po dobu 2 let. Významným parametrem se ukázalo udržení léčebné odpovědi po vysazení risankizumabu. 6 měsíců po vysazení risankizumabu docházelo k pomalé ztrátě léčebné odpovědi: PASI 100 si udrželo $30 \%$ pacientů, PASI 90 si udrželo $52 \%$ pacientů $(16,17)$.

Studie IMMvent byla multicentrická, randomizovaná, dvojitě zaslepená studie III. fáze, do které bylo zařazeno 605 pacientů s chronickou ložiskovou psoriázou s hodnotami $\mathrm{BSA} \geq 10, \mathrm{PASI} \geq 12$ a sPGA $\geq 3$. Na začátku první části studie byli pacienti v poměru $1: 1$ náhodně prirǐazeni k terapii risankizumabem (150 mg s. c. v týdnech 0, 4 a poté každých 12 týdnů) nebo k léčbě adalimumabem (80 mg s. c. v týdnu 0, 40 mg v týdnu 1 a následně každé 2 týdny); koprimárním sledovaným parametrem $v$ této části bylo dosažení PASI 90 a sPGA 0/1 v 16. týdnu, sekundární sledované parametry zahrnovaly četnosti PASI 75 a PASI 100 v 16. týdnu. Ve druhé části studie (týden 16-44) pokračovali pacienti ze skupiny risankizumabu v dosavadní terapii, zatímco u nemocných ze skupiny adalimumabu se další postup odvijjel od léčebné odpovědi dosažené v 16. týdnu: pacienti s odpovědí horší než PASI 50 byli převedeni na risankizumab, pacienti s odpovědí PASI 90 pokračovali v léčbě adalimumabem a pacienti s odpovědí v rozmezí PASI 50 až PASI 90 byli znovu randomizováni k terapii risankizumabem nebo adalimumabem. Primárním sledovaným parametrem ve druhé části studie bylo dosažení PASI 90 ve 44. týdnu, sekundárním sledovaným parametrem bylo dosažení PASI 100 ve 44. týdnu. Vyhodnocováno bylo rovněž dosažení dalších odpovědí dle kritérií PASI a sPGA či změna skóre DLQI v 16. a 44. týdnu (18). Studie IMMvent prokázala vyšší účinnost risankizumabu oproti adalimumabu - v 16. týdnu činily podíly pacientů s PASI 9072 \% vs. 47 \%, se skóre sPGA 0/1 $84 \%$ vs. $60 \%$, s PASI $7591 \%$ vs. $72 \%$, s PASI $10040 \%$ vs. $23 \%$ a se skóre sPGA $041 \%$ vs. $23 \%$ (ve všech prípadech $p<0,0001$ ).

Ze skupiny znovu randomizovaných pacientů dosáhlo PASI 90 ve 44. týdnu 66 \% nemocných převedených na risankizumab vs. 21 \% nemocných pokračujících v léčbě adalimumabem, skóre sPGA 0/1 pak bylo potvrzeno u $74 \%$ vs. $34 \%$ pacientů, odpověd'PASI 75 u 91 \% vs. 46\%, odpo-

Tab. 1. Skupina aktuálně léčených pacientů

\begin{tabular}{|l|l|}
\hline Pohlaví & Muži 7, Ženy 7 \\
\hline Věk (roky) & $47(28-57)$ \\
\hline Trvání od stanovení diagnózy (roky) & $19(5-38)$ \\
\hline Trvání do zavedení biologika (měsíce) & $65(3-168)$ \\
\hline Naivní & 6 \\
\hline Switch & 8 (4 jedno biologikum, 2 dvě biologika, 2 tři biologika) \\
\hline Léčba risankizumab (měsíce) & $4,5(3-6)$ \\
\hline Dosažení PASI 90 (týdny) & 4. týden 6 pacientů, 12. týden 2 pacienti \\
\hline Dosažení PASI 100 (týdny) & 4. týden 6 pacientů, 12. týden 5 pacientů, 16. týden 1 pacient \\
\hline Nú & $\begin{array}{l}3 \times \text { respirační infekt lehkého stupně, 1× primoinfekce herpes } \\
\text { progenitalis }\end{array}$ \\
\hline
\end{tabular}

věd'PASI 100 u 40 \% vs. $7 \%$ a skóre sPGA 0 taktéž u 40 \% vs. 7 \% pacientů. Parciální respondéři na adalimumab (PASI 50-89) dosáhli vyšší účinnosti po včasném převedení na risankizumab (18).

\section{Bezpečnost v klinických studiích}

Krátkodobá bezpečnost risankizumabu (16 týdnů léčby) byla vyhodnocována u pacientů léčených ve výše uvedených pěti studiích II. a III. fáze ( $n=2232)$, dlouhodobá bezpečnost risankizumabu (až 40 týdnů) byla analyzována u nemocných léčených v těchto pěti studiích a dále ve dvou studiích I. fáze, v jedné studii II. fáze a ve studii LIMMitless ( $n=2234)$ (19).

S ohledem na krátkodobou bezpečnost, výskyt nežádoucích účinků (Nú) byl v jednotlivých ramenech (risankizumab, ustekinumab, adalimumab, placebo) obecně podobný, přičemž většina Nú byla pouze mírná či středně těžká. Závažné Nú pak byly hlášeny u 2,4\% (risankizumab) vs. u 5,0 \% (ustekinumab), resp. 3,0 \% (adalimumab), resp. 4,0\% (placebo). S ohledem na dlouhodobou bezpečnost risankizumabu, nejčastějšími Nú byly virové infekce horních cest dýchacích, dalšri infekce horních cest dýchacích, artralgie a bolest hlavy. Četnost Nú i závažných Nú se v čase nezvyšovala, byla stabilní. Nebyly zaznamenány žádné nové a nepředvídané závažné nežádoucí účinky. Frekvence fungálních infekcí (3,4/100 pacient/rok) i oportunních infekcí (0,3/100 pacient/rok) při dlouhodobém sledování byla nízká. Při terapii risankizumabem nebyl hlášen žádný prípad aktivní tuberkulózy. Výskyt malignit byl popsán u šesti (0,5%) pacientů léčených risankizumabem vs. u žádného pacienta léčeného ustekinumabem, jednoho pacienta léčeného adalimumabem a jednoho pacienta užívajícího placebo. U nemocných léčených risankizumabem byly zaznamenány tři nemelanomové kožní nádory, karcinom prsu, maligní melanom a karcinom jícnu, u žádného z těchto nádorů ne- byla prokázána souvislost s terapií. Risankizumab nemá žádné kontraindikace pro střevní zánětlivá onemocnění, roztroušenou sklerózu, kongestivní srdeční selhání nebo deprese (19).

\section{Vlastní skupina pacientů}

Z klinického pohledu, nikoli statisticky významně, předkládáme skupinu našich 14 léčených pacientů prípravkem risankizumab (Tab. 1). První pacient zařazen v 1. 10. 2019. Vzhledem k tomu jsme mohli zhodnotit pouze krátkodobý efekt a bezpečnost terapie. U všech pacientů se jednalo o diagnózu chronické ložiskové psoriázy, ve 2 prípadech navíc o psoriázu pustulózní palmoplantární.

\section{Závěr}

Risankizumab je dalším schváleným biologikem v terapii psoriázy se specifickou inhibicí lL-23. Proběhlé registrační studie prokázaly, že risankizumab je vhodný zejména pro léčbu pacientů bionaivních, pacientů selhávajících na ustekinumabu (UltiMMA-1, 2), selhávajících na adalimumabu (IMMvent), u těžko léčitelné populace - selhané 1 či 2 předchozí léčby, non-respondérů na anti-TNF alfa léčbu i jinou nežanti-TNF alfa léčbu. Risankizumab demonstruje konzistentní vysokou účinnost u všech typů pacientů bez ohledu na hmotnost, BMI, závažnost onemocnění či PsA - dosažení PASI 90 v týdnu 16 je konzistentní (71-81 \% pacientů např́č všemi skupinami). Kompletního zhojení psoriázy (PASI 100) dosáhlo ve studii UltiMMa-1 35,9\% pacientů léčených risankizumabem oproti $12 \%$ s ustekinumabem.

Ve studii UltiMMa-2 dosáhlo PASI 100 s risankizumabem 50,7 \% pacientů oproti 24,2 \% s ustekinumabem. Ve studii IMMvent signifikantně více pacientů dosáhlo v 16. týdnu PASI 90 při léčbě risankizumabem než adalimumabem (72 \% vs. 47 \%). Z nových studií vyplývá, že nová biologická léčba s novým mechanismem účinku je lepší 
než starší známé inhibitory. V naší skupině pacientů byl nejčastějším předcházejícím biologikem adalimumab, dále etanercept, v jednom prípadě také ustekinumab a ixekizumab. Pro pacienty byl významný rychlý nástup účinku, risankizumab byl účinný již po 2 dávkách (v týdnu 0 a 4), kdy bylo dosaženo PASI 90, v 6 prípadech i PASI 100, tj. úplného

\section{LITERATURA}

1. Harden JL, Krueger JG, Bowcock AM. The immunogenetics of psoriasis: a comprehensive review. J Autoimmun 2015; 64: 66-73. 2. WHO. 2016 Global report on psoriasis. 2016. Dostupné z: http://www.who.int/ iris/handle/10665/204417 (accessed Sept 12, 2018)

3. Takeshita J, Grewal S, Langan SM, et al. Psoriasis and comorbid diseases: epidemiology. J Am Acad Dermatol 2017; 76: 377-390

4. Yeung H, Takeshita J, Mehta NN, et al. Psoriasis severity and the prevalence of major medical comorbidity: a population-based study. JAMA Dermatol 2013; 149: 1173-1179.

5. Girolomoni G, Strohal R, Puig L, et al. The role of IL-23 and the $\mathrm{IL}-23 / \mathrm{T}<\mathrm{sub}>\mathrm{H}</$ sub $>17 \mathrm{immune}$ axis in the pathogenesis and treatment of psoriasis. J Eur Acad Dermatol Venereol 2017; 31: 1616-1626.

6. Cetkovská P, Kojanová M, Arenberger P, Fabiánová J. Současný stav moderní léčby psoriázy - aktualizovaná doporučení ČDS JEP k cílené léčbě závažné chronické psoriázy. Farmakoterapie 2020; 16(supplementum 2): 5-28.

7. Hawkes JE, Yan BY, Chan TC, Krueger JG. Discovery of the zhojení. Počet zcela zhojených pacientů se zvýšil $v$ týdnech 12 a 16. U jednoho pacienta zůstalo dosažení PASI 90 i v 16. týdnu, u dalšího pouze PASI 75 v 16. týdnu. Pozitivní byl vliv léčby na psoriatické postižení kštice (skóre PSSI - Psoriasis Scalp Severity Index), dlaní a plosek (skóre PPASI - Palmoplantar PASI) či nehtů (skóre NAPSI - Nail Psoriasis Severity

IL-23/IL-17 signaling pathway and the treatment of psoriasis. J Immunol. 2018; 201(6).

8. Di Meglio P, Nestle FO. The role of IL-23 in the immunopathogenesis of psoriasis. F1000 Biol Rep. 2010; 2: 40 9. Gaffen SL, Jain R, Garg AV, Cua DJ. The IL-23-IL-17 immune axis: from mechanisms to therapeutic testing. Nat Rev Immunol. 2014; 14(9): 585-600.

10. Cheuk S, et al. Epidermal Th22 and Tc17 Cells From a Localized Disease Memmory in ClinicallyHealed Psoriasis. J Immunol 2014; 192: 3111-3120.

11. McKeage K, Duggan S. Risankizumab: First global approval. Drugs 2019; 79: 893-900.

12. Skyrizi, Souhrn informací o prípravku, 2019.

13. Torres T. Selective interleukin-23 p19 inhibition: Another game changer in psoriasis? Focus on risankizumab. Drugs 2017; 77: 1493-1503.

14. Papp KA, Blauvelt A, Bukhalo M, et al. Risankizumab versus ustekinumab for moderate-to-severe plaque psoriasis. N Engl J Med 2017; 376: 1551-1560.

15. Gordon KB, Strober B, Lebwohl M, et al. Efficacy and safety
Index) a na kvalitu života pacientů (skóre DLQI Dermatology Life Quality Index). Výskyt Nú byl srovnatelnýs běžnou populací, pacienti pozitivně hodnotili minimální reakci v místě vpichu podkožní injekce ve srovnání s prededchozími léčivy. Dalším pozitivem je úsporné dávkovací schéma s aplikací v týdnu 0, 4 a dále každý 12. týden.

of risankizumab in moderate-to-severe plaque psoriasis (UItIMMa-1 and UItIMMa-2): results from two double-blind, randomised, placebo-controlled and ustekinumab-controlled phase 3 trials. Lancet 2018; 392: 650-661.

16. Blauvelt A, Papp KA, Gooderham M, et al. Risankizumab efficacy/safety in moderate-to-severe plaque psoriasis: 16 week results from immhance. Acta Derm Venereol 2018 98(Suppl 219): 30(abstract P066).

17. Langley R, Blauvelt A, Gooderham M, et al. Efficacy and safety of continuous Q12W risankizumab versus treatment withdrawal: results from the phase 3 IMMhance trial. 2019 AAD Annual Meeting, poster 10093

18. Reich K, Gooderham M, Thaçi D, et al. Risankizumab compared with adalimumab in patients with moderate-to-severe plaque psoriasis (IMMvent): a randomised, doubleblind, active-comparator-controlled phase 3 trial. Lancet 2019; 394(10198): 576-586

19. Leonardi C, Bachelez H, Wu JJ, et al. Long-term safety of risankizumab in patients with moderate to severe psoriasis: analysis of pooled clinical trial data. 2019 AAD Annual Meeting, poster 9891. 